\title{
California's cattle and beef industry at the crossroads
}

\section{Matt A. Andersen \\ Steven C. Blank \\ Tiffany LaMendola \\ Richard J. Sexton}

Beef cattle remain one of California's most important agricultural products, ranking fifth in 2001 at $\$ 1.35$ billion in value of production, behind dairy, grapes, nursery products and lettuce. However, technological change, coupled with declining consumption of red meats during the 1970s and 1980s, triggered a wave of mergers and acquisitions in the beef-processing sector. To evaluate how such trends are affecting the industry in California, we undertook a survey during 2000 and 2001 and obtained responses from ranchers in 40 counties. Our results confirm that the industry appears to be at a crossroads, for a variety of reasons. Cow-calf ranching operations now predominate, and a significant percentage of cattle leave the state for feeding and slaughter. Auction yards, a principal marketing outlet for most of the survey respondents, require a large volume of activity in order to operate efficiently. As aging ranchers exit the business, this important exchange mechanism is threatened, possibly contributing to the industry's further decline. Most ranchers reported having five or fewer potential buyers for their cattle.

$T$ he cattle and beef sectors in the United States have evolved in rapid and fundamental ways. The "boxed-beef" technology introduced in the 1960s and concurrent advances in shipping technology have enabled carcasses to be processed into indi-

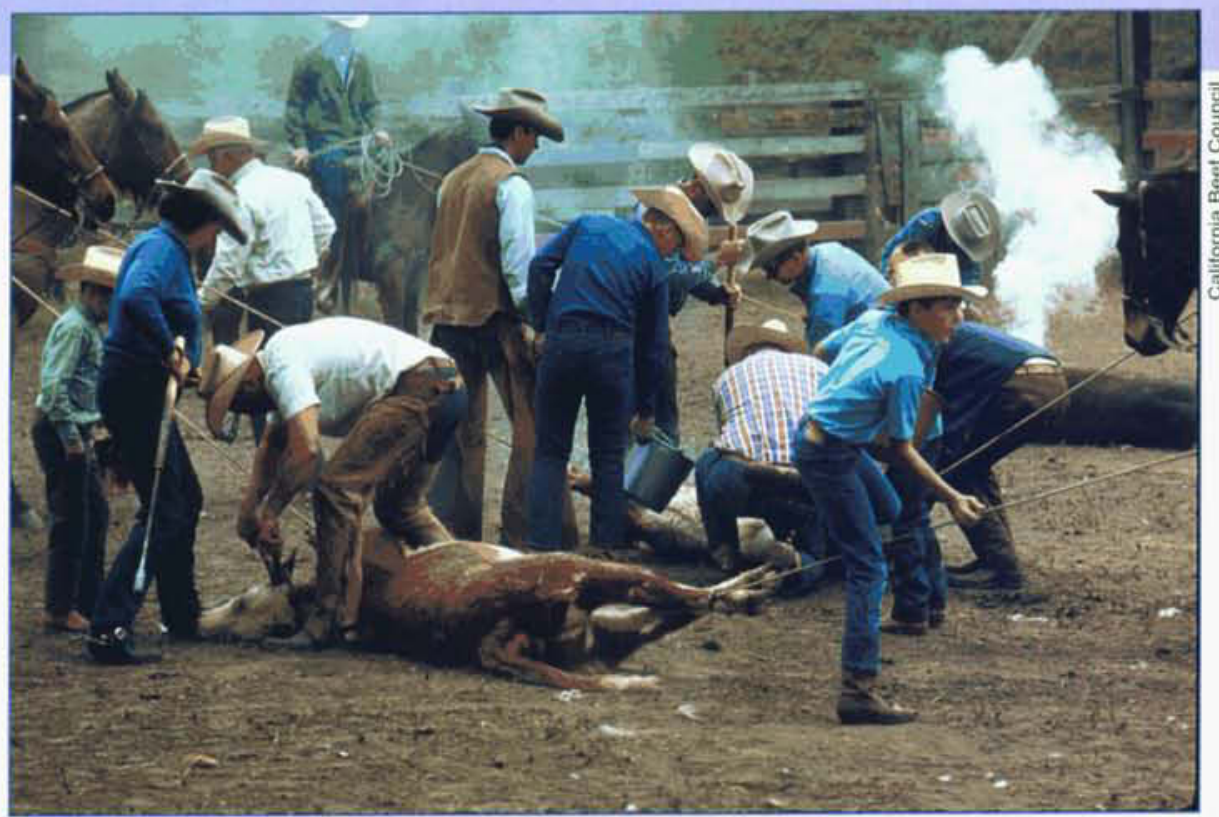

While cattle and beef are California's fifth most valuable agricultural product, the industry is struggling due to technological change and consolidation. Cattle are rounded up at a California ranch.

vidual cuts, packed and shipped nationally or internationally from the same plant where slaughter took place. This capital-intensive technology resulted in expanded economies of scale. Technological change, coupled with declining consumption of red meat during the 1970 s and 1980 s, triggered a wave of mergers and acquisitions in the beef-processing sector. In 1977, the four leading beef packers were estimated to hold $30 \%$ of total U.S. slaughter capacity; by 1999 that share had risen to $82 \%$. Analysts generally agree that this technological change, coupled with the increase in packer concentration, has increased efficiency in the processing sector (Morrison-Paul 2000). However, benefits to producers from enhanced efficiency can be dissipated or eliminated if packers are able to exercise market power as a result of industry consolidation (USDA 1996; Azzam and Schroeter 1997).

Rapid change has also occurred in the marketing arrangements between cattle producers and beef processors. In particular, there is evidence of tighter vertical control, such as packerfed cattle, producer-packer forward contracts, and marketing agreements between producers and packers wherein cattle are priced according to a predetermined formula. All of these arrangements are lumped under the term "captive supplies" because the cattle are tied ex ante to a particular processor, and not sold on the open market.

Empirical evidence from various markets suggests a negative correlation between the use of captive supplies in a region and the cash-market price (Ward 2002). Accordingly, various producer groups, government regulators and academics have expressed concern about the evolution of these marketing arrangements, especially in light of rising packer concentration and reduced selling opportunities for producers. A ban on packer feeding was debated but not included in the Farm Bill that recently passed, and is now being debated by Congress as a stand-alone piece of legislation.

Most of the aforementioned investigation has focused on the major cattle- 
producing states in the Midwest, and comparatively little attention has been paid to California's cattle industry. However, beef cattle and calves remain one of California's most important agricultural products, ranking fifth (behind dairy, grapes, nursery products and lettuce) in 2001 value of production at $\$ 1.35$ billion. Cattle and calves were the leading agricultural commodity, based on value of production, for nine California counties: Calaveras, Imperial, Mariposa, Nevada, Plumas, Shasta, Sierra, Trinity and Tuolumne. They are second in importance in six others: Amador, Inyo, Marin, Modoc, Placer and San Bernardino.

Because of its importance to California's agricultural economy and the comparative neglect it has received in the multitude of studies conducted on the U.S. cattle and beef industry (Ward
2002), we undertook an investigation of the status of those industries in California. The main goal was to document the evolution of production and marketing and to obtain a perspective on the impacts of increasing packer concentration and vertical coordination on the California industry.

\section{Cattle production and processing}

California's greatest concentrations of cattle are in the Central Valley counties of Fresno, Kern, Merced, Stanislaus and Tulare, and the arid southern region comprised by Imperial, Riverside and San Bernardino counties (fig. 1). Although cattle production is a leading agricultural industry for such northern counties as Modoc, Plumas, Shasta, Sierra and Trinity, production in those counties pales relative to the Central Valley and southern counties.

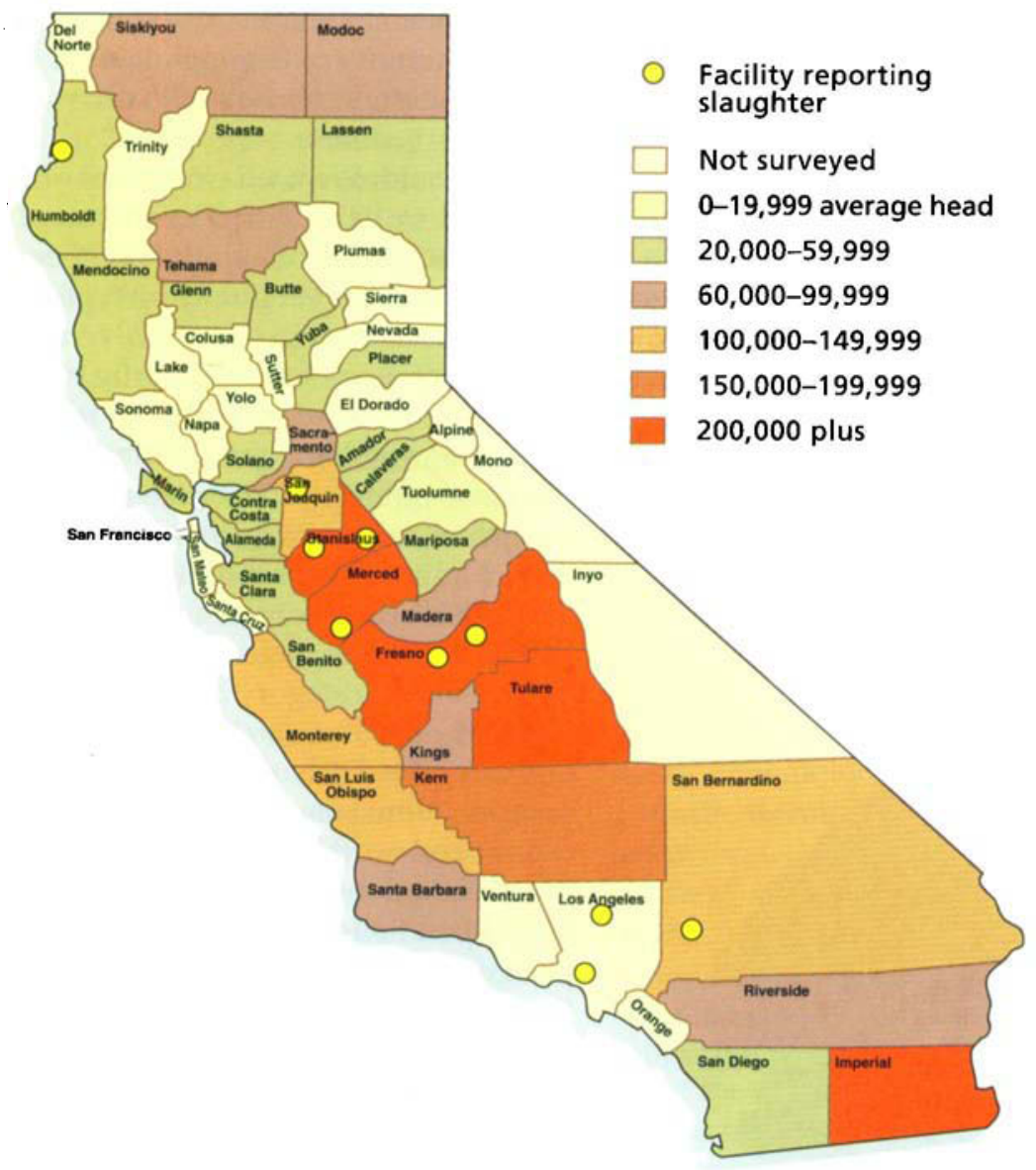

Fig. 1. Cattle and calves, average inventory levels by county, 1982-1997, and locations of facilities reporting slaughter of cattle and calves, 1997. Sources: California Census of Agriculture; USDA Grain Inspection, Packers and Stockyards Administration.
The major growth has occurred in the Central Valley and desert-south regions, with an additional pocket of growth in North Coast counties such as Del Norte, Humbolt, Mendocino and Trinity (fig. 2). Not surprisingly, cattle production has declined in the counties that represent the major urban growth corridors within the state, particularly the central- and south-coast regions.

In 1997, 10 facilities in California reported slaughter of cattle and calves to the U.S. Department of Agriculture (USDA)(fig. 1). Only three of those process significant numbers of cattle: an IBP plant in Fresno, Harris Ranch in Coalinga and Shamrock Meats in Los Angeles. The others are small specialty operations that do not contribute importantly to the state's processing capacity. By way of contrast, 52 facilities reported slaughter of cattle and calves to USDA in 1972. Due to the rapid decline in its slaughter capacity, California is now a significant net exporter of live cattle for slaughter, with cattle being shipped to plants in locations ranging from Washington to Utah and Colorado. Long-distance shipping of cattle is costly, due both to the transportation costs and stress on the animals, so the necessity of such travel reduces the profitability of cattle production in California.

\section{Producer survey}

Only a limited amount of information specific to California cattle production can be gleaned from the standard statistical sources, so we undertook a survey of cattle producers in the state during 2000 and 2001. To facilitate the survey, we cooperated with county-level UC Cooperative Extension livestock advisors. The county personnel contributed to development of the survey and distributed the survey forms, either in-person, at trade shows or through the mail. To further encourage compliance, we kept the survey form short, one double-sided page with 12 categorical or shortanswer questions, focusing primarily upon marketing issues.

In total, we received 280 completed surveys. We obtained responses from 


\begin{tabular}{|c|c|c|c|c|c|}
\hline & $1-50$ & $51-150$ & $151-300$ & $300+$ & Total \\
\hline Calves & 109 & 61 & 36 & 25 & 231 \\
\hline Cull cows/bulls & 181 & 25 & 4 & 6 & 216 \\
\hline Yearlings & 82 & 41 & 20 & 25 & 168 \\
\hline Fed cattle & 26 & 7 & 2 & 17 & 52 \\
\hline Total responses & 398 & 134 & 62 & 73 & \\
\hline
\end{tabular}

ranchers in 40 of California's 58 counties. Counties with the most respondents were Shasta (66), Stanislaus (58), Merced (58) and Calaveras (34). (A single respondent might operate, and hence be counted, in multiple counties.) We focused the survey on three regions of the state to see if there are geographic differences in industry structure and marketing opportunities. The north region was centered in Lassen, Shasta and Tehama counties. The central region focused on Stanislaus and surrounding counties, while the coastal region included counties ranging from Humboldt to Monterey. In general, our survey results indicate that average ranches in the north and central regions are virtually identical in size, herd composition and marketing strategies. Ranches in the coastal region, on average, are much smaller and more often parttime operations.

Land ownership. The vast majority of respondents (246) owned some of their own ranch land and also rented additional land in either the summer

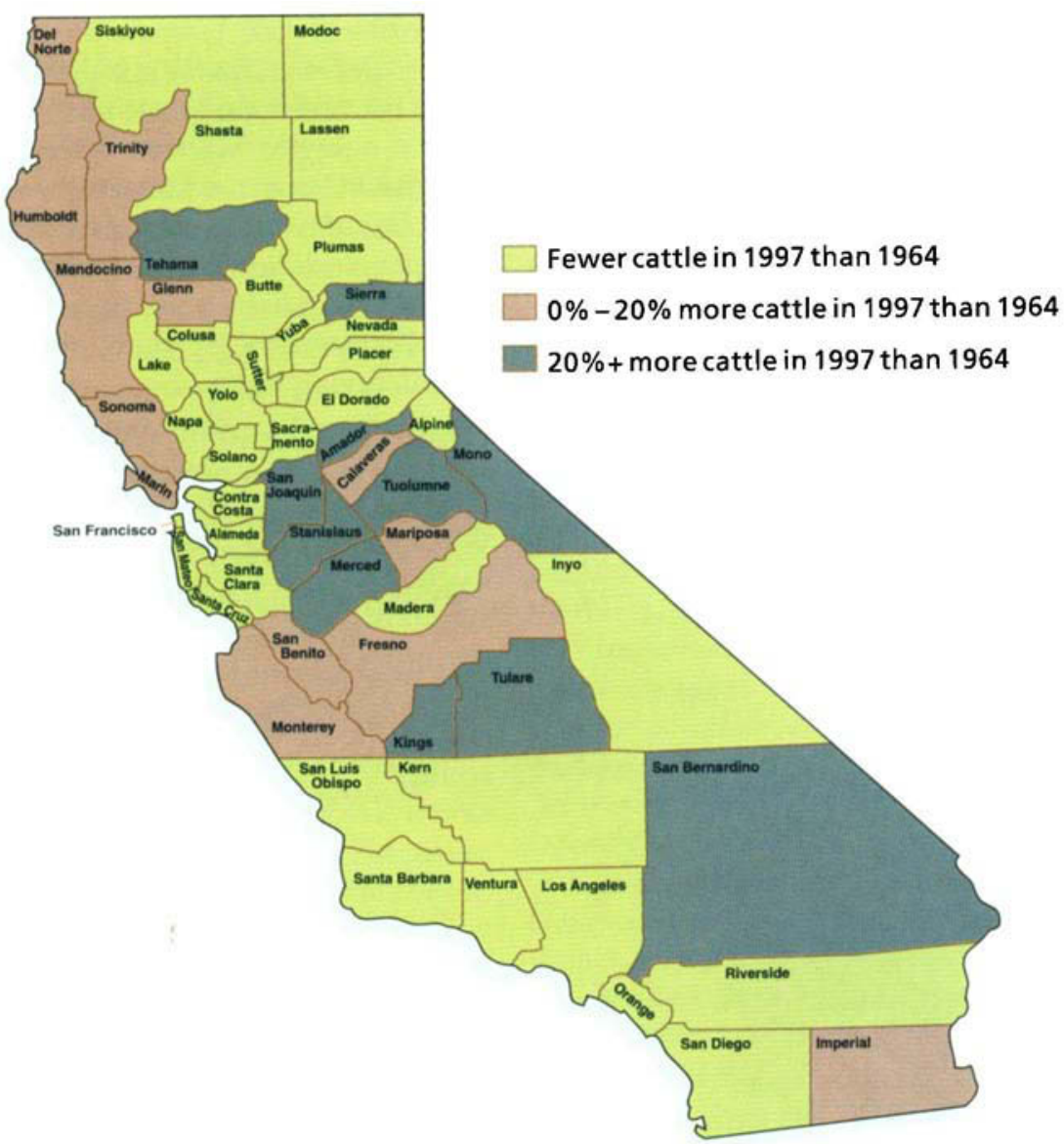

Fig. 2. Cattle and calves (excluding milk cows), percentage change in inventory levels, 1964-1997. Source: California Census of Agriculture.

or winter. In particular, 178 rented summer land and 167 rented winter land from private parties, while 38 reported renting summer land and 12 reported renting winter land from the U.S. Bureau of Land Management or Forest Service.

Ranching experience. The average years of experience in ranching among the survey respondents was 34.9 , meaning that ranching has been a lifetime operation for most and that, collectively, they represent a wellseasoned group. Most of the operations are family oriented, so the fact that many operators appear to be nearing retirement age raises questions about continuity of the operations if sons/daughters choose not to carry on the family business.

Cattle sold. We used categories of 1 to 50,51 to 150,151 to 300 , and more than 300 to inquire about the number of cattle marketed annually by type (table 1). Ranchers in the north, central and coastal regions are primarily cowcalf operators, who specialize in raising and marketing young cattle and cull cows or bulls. In particular, relatively few engage in feedlot operations. Only $16 \%$ of respondents in the north, $20 \%$ in the central and $8 \%$ in the coastal region marketed fed cattle.

The largest category of response for all types of cattle was the 1 to 50 animal category. Such operations represent part-time businesses. In the central and north regions, calves and yearlings are the primary focus, and large operations make up a significant part of the industry. For example, in the central region, $11 \%$ of ranches sell more than 300 calves per year, and $12 \%$ of ranches sell more than 300 yearlings annually. These operations are clearly full-time business with sizeable assets invested.

Sales mechanisms. We also asked respondents to indicate the selling 


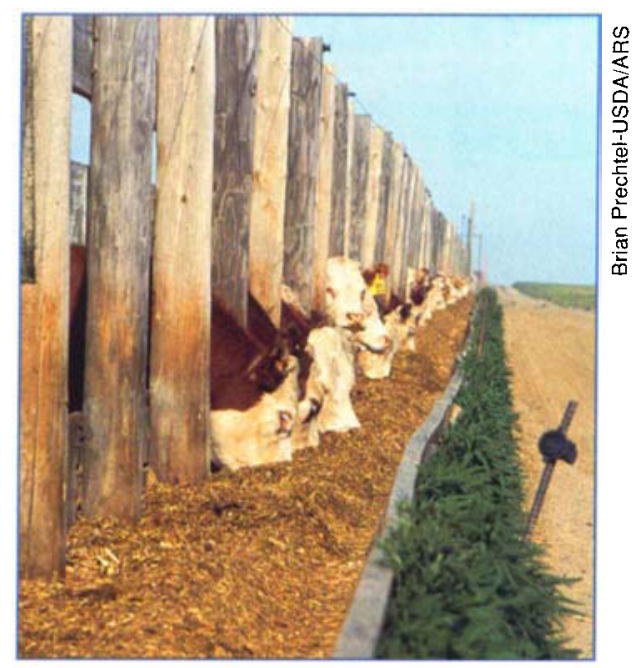

In a survey covering nearly 300 ranches in 40 counties, the authors found that only $29 \%$ of the state's cattle destined for feedlots remained in California, with the rest shipped to the U.S. Northwest, Midwest and Southwest.

mechanism they utilized to market their cattle. The predominant marketing mechanism among the respondents in all regions was the traditional, privately operated auction sale yard, which 240 reported utilizing for at least some sales. Sixty-one ranchers also indicated using an auction operated by a cattle association. One hundred five respondents reported direct sales to local buyers, with 52 reporting direct sales to regional or national buyers. Interestingly, the much-touted "high-tech" selling mechanisms, such as video and electronic auctions, were used infrequently by the respondents 27 reported using a video auction (none from the coastal region) and only one person reported using an electronic auction.

An important point in considering the marketing tools utilized by California ranchers is that substantial economies of scale exist with respect to some selling mechanisms, including various forms of direct sales and video or electronic auctions. The standard trucks used to haul cattle accommodate, for example, upwards of 50 yearling calves. Ranchers who cannot provide at least this much volume in a sales transaction are at a competitive disadvantage. Private or cattle-association auction yards represent the primary sales outlet for these small-scale producers because buyers can rather easily aggregate small lots from various sellers to attain truck capacity. For example, among the respondents to our survey, 93 marketed more than 150 cattle annually in at least one of the four categories indicated in table 1. Among this group of larger producers, 35 (37.6\%) reported sales to regional or national buyers, whereas only $17(10.2 \%)$ of the 167 with sales of 150 cattle or less in any category were able to attract the interest of these buyers. Due to the rising concentration in the industry, it is important for ranchers to be able to access the widest pool of potential buyers possible.

Other marketing tools. Our respondents were reluctant to use futures and/or options contracts, with only $6 \%$ reporting use of these marketing tools (none from the coast). Similarly, the much discussed and disputed captive-supply mechanisms were little in evidence among our respondents, with only $8.6 \%$ reporting using either forward contracts or marketing agreements. The limited use of these marketing tools is due in part to the fact that California ranchers in most cases are not selling cattle directly to packers, where these mechanisms have been used most widely, and also due to the small scale of many respondents' operations.

Cattle destinations. Most likely due to the limited processing capacity in the state, a large portion of California production nowadays consists of young cattle, which are then sold for fattening elsewhere. This conclusion is supported by responses to a question about the cattle's destination after leaving the producers' ranch. A total of 135 respondents indicated that cattle were headed for further development on grassland, while 205 indicated that cattle were destined for a feedlot. Only 58 reported making sales directly to a packinghouse. (Totals sum to more than the number of survey responses because ranchers may have multiple destinations for their cattle.)

Among the cattle destined for further development on rangeland, 53\% were reported to remain in California, with Northwestern states (Idaho, Oregon and Washington) representing the second-most reported destination. Among the cattle destined for feedlots, only $29 \%$ remained in California, with $19 \%, 16 \%$ and $12 \%$ destined for feedlots in the Northwest, Midwest (Kansas, Nebraska) and Southwest (Arizona, Nevada, New Mexico, Texas), respectively. Nearly $62 \%$ of cattle destined for packinghouses remained in California, based upon survey responses.

Potential buyers. Finally, because of the consolidation among firms in the beef sector, we asked about the number of potential buyers available to cattle: producers in a given selling enviromment. The respondents indicated either onc, iwo, three to five, or more than five potential buyers. The modal response (with a total of 115) was three to five buyers. Ninety-eight ranchers (more often from the central region) reported more than five buyers, with 29 reporting only one or two possible buyers. A firm consensus has not emerged among economists as to the number of 0 buyers needed to create a competitive selling environment. Most, however, would agree that five or fewer buyers represent an oligopsony market setting, where buyer market power is a potential concern.

\section{Future of California beef industry}

While cattle production remains one of California's most important agricultural industries, it is now at a crossroads, for a variety of reasons. As 

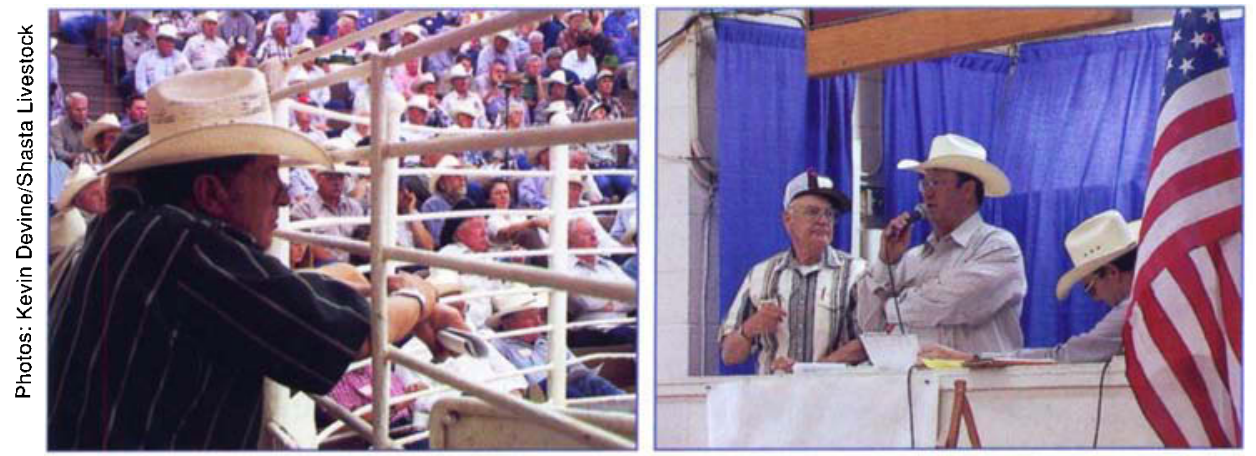

Concerned about economic trends that are leaving them with a shrinking percentage of the beef dollar, cattle ranchers gathered at the Shasta Livestock Auction in Cottonwood in June to discuss futures contracts, packer concentration and improved cooperation among producers. Left, Duane Martin of Clements, Calif., helped organize the meeting. Right, Ellington Peek of Shasta Livestock looks on as Ron Anderson moderates.

noted, many operators of these predominantly family-run businesses are nearing retirement age, with uncertain prospects for continuity of the family operations. Moreover, the state's industry now consists predominantly of cow-calf ranching operations, with a significant share of cattle leaving the state for feeding and slaughter. A key factor in explaining the paucity of feeding operations in the state is California's status as a net importer of feed grains such as corn. This status was reinforced through the 1990s when significant acreage in California moved from annual crops such as corn and wheat to perennial tree and vine crops (Blank 2000). Feed grains for cattle are now grown in California primarily as a rotation crop. In practical terms, it is cheaper to incur the onetime expense of hauling the steer to the feed than to continuously haul the feed to the steer.

Because of the expense and risk of shipping fattened cattle long distances, it is economical to locate processing facilities in close proximity to feedlots, helping to explain the exodus of packing facilities from California. The transaction costs associated with outof-state shipment inevitably place California at a competitive disadvantage relative to states (such as Colorado, Kansas, Nebraska and Texas) and regions (such as the Midwest and Southwest) that combine substantial capacity in production, feeding and processing. Moreover, the lack of local selling alternatives may place California producers in a disadvantageous competitive position in dealings with out-of-state buyers.

The rangeland utilized for cattle production in California often has few alternative uses, except other grazing operations. This fact may explain the resiliency of this segment of the cattlebeef chain, despite the generally poor economic climate for cattle production in recent years, and the mid-1990s in particular, when weak demand and the high-production phase of the cattle cycle caused most producers to lose money. Nonetheless, the long-run viability of these operations requires a stream of revenues that is at least sufficient to compensate for all costs, including opportunity costs for owned land and operator labor. Achieving such revenues will be a challenge if the state continues to operate with cost disadvantages relative to competing states. The auction yards, which provide the principal marketing outlet for most of the survey respondents, require a large volume of activity in order to operate efficiently. If some ranchers exit the business, their departure will impose external costs on those who remain by threatening the vitality of these exchange mechanisms. In turn, if spot-market exchanges wane, ranchers will be compelled to expand or consolidate to attain the selling economies needed to participate in direct sales or other high-tech selling mechanisms.

Furthermore, feedlots and packing plants are not popular enterprises in a populous and environmentally conscious state like California due to odor and waste-disposal issues. However, these operations provide favorable marketing outlets for California's ranch operators and, hence, affect the vitality of the entire cattle-beef sector. The political challenges in gaining approval for such facilities notwithstanding, the economics of these operations favor locating them in regions with extensive feed-grain production, so California is at a cost disadvantage. For a variety of reasons, there is little chance that these operations will expand in California and they may well continue to decline. California cattle ranchers must continue to search for marketing innovations that will enable them to compete effectively in a challenging environment.

M.A. Andersen is Graduate Student, S.C. Blank is Cooperative Extension Specialist, and R.J. Sexton is Professor, Department of Agricultural and Resource Economics, UC Davis; and T. LaMendola is Director of Economic Research, Western United Dairymen. Blank is Member and Sexton is Director, Giannini Foundation of Agricultural Economics. We gratefully acknowledge the contributions to this project by Larry Forero, Franz Rolofson, Jim Farley, Marc Horney and Glen Nader, UC Cooperative Extension livestock advisors.

\section{References}

Azzam A, Schroeter JR. 1997. Concentration in beef packing: Do gains outweigh losses? Choices (1st quarter):26-8.

Blank S. 2000. is this California agriculture's last century? Cal Ag 54(4):23-5.

Morrison-Paul CJ. 2000. Cost Economies and Market Power in U.S. Beef Packing. Giannini Foundation Monograph No. 44, UC ANR. $66 \mathrm{p}$.

[USDA] US Department of Agriculture. 1996. Concentration in the Red Meat Packing industry. Grain Inspection, Packers and Stockyards Administration. $86 \mathrm{p}$.

Ward CE. 2002. A review of causes for and consequences of economic concentration in the U.S. meatpacking industry. Current Ag, Food \& Resource issues 3:1-28. 